\title{
Listeria monocytogenes in Milk: Occurrence and Recent Advances in Methods for Inactivation
}

\author{
Sarah Hwa In Lee ${ }^{1}$, Leandro Pereira Cappato ${ }^{2}$, Jonas Toledo Guimarães ${ }^{2}$, \\ Celso Fasura Balthazar ${ }^{2}$, Ramon Silva Rocha ${ }^{3}$, Larissa Tuanny Franco ${ }^{1}$, \\ Adriano Gomes da Cruz ${ }^{3}$, Carlos Humberto Corassin ${ }^{1}$ and \\ Carlos Augusto Fernandes de Oliveira $1, *$ (D)
}

1 Department of Food Engineering, School of Animal Science and Food Engineering, University of São Paulo, Av. Duque de Caxias Norte, 225, Pirassununga CEP 13635-900, SP, Brazil; sarah.hwa.in.lee@gmail.com (S.H.I.L.); lafranco@usp.br (L.T.F.); carloscorassin@usp.br (C.H.C.)

2 Department of Food Technology, Veterinary School, Federal Fluminense University, Rua Vital Brazil Filho, 64, Niterói CEP 24230-340, RJ, Brazil; leandrocappato@gmail.com (L.P.C.); jonasguimaraes@gmail.com (J.T.G.); celsofasura@id.uff.br (C.F.B.)

3 Department of Food Science, Federal Institute of Education, Science and Technology of Rio de Janeiro, Rio de Janeiro CEP 20270-021, RJ, Brazil; ramonsg@globo.com (R.S.R.); food@globo.com (A.G.d.C.)

* Correspondence: carlosaf@usp.br; Tel.: +55-19-3565-4173

Received: 18 December 2018; Accepted: 25 January 2019; Published: 1 February 2019

\begin{abstract}
Milk is one of the most important food items consumed by humans worldwide. In addition to its nutritional importance, milk is an excellent culture medium for microorganisms, which may include pathogens such as Listeria monocytogenes (L. monocytogenes). Traditional processing of milk for direct consumption is based on thermal treatments that efficiently eliminate pathogens, including pasteurization or sterilization. However, the occurrence of L. monocytogenes in milk as a consequence of failures in the pasteurization process or postpasteurization contamination is still a matter of concern. In recent years, consumer demand for minimally processed milk has increased due to the perception of better sensory and nutritional qualities of the products. This review deals with the occurrence of L. monocytogenes in milk in the last 10 years, including regulatory aspects, and recent advances in technologies for the inactivation of this pathogen in milk. The results from studies on nonthermal technologies, such as high hydrostatic pressure, pulsed electric fields, ultrasounds, and ultraviolet irradiation, are discussed, considering their potential application in milk processing plants.
\end{abstract}

Keywords: L. monocytogenes; occurrence; milk; non-thermal treatments; high pressure processing (HPP); pulsed electric fields (PEFs); ultrasound; irradiation

\section{Introduction}

Milk is the fluid secreted by mammals for the nourishment of their offspring [1]. Since humans began to domesticate lactating animals, milk and milk products have been part of the human diet [2]. Milk is considered one of the most complete sources of nutrients for human beings because of its diverse components, such as proteins, vitamins, and minerals that are important in human nutrition [3,4].

However, due to its high nutritional value, neutral $\mathrm{pH}$, and high water activity, raw milk serves as an excellent growth medium for different microorganisms, whose multiplication depends mainly on temperature and on competing microorganisms and their metabolic products [5]. Raw milk also creates good growth conditions for a variety of spoilage and potentially pathogenic microorganisms, such as Shiga toxin-producing Escherichia coli (STEC), Listeria monocytogenes (L. monocytogenes), Salmonella enterica, Campylobacter spp., Yersinia spp., and others [6,7]. 
Due to the adoption of pasteurization in 1938, milk-borne disease outbreaks have decreased [8]. Different heat treatments can be distinguished based on the temperature and time conditions applied, and include subpasteurization, pasteurization, and sterilization, including ultrahigh temperature (UHT) and innovative steam injection (ISI) treatment [9]. Sterilization $\left(110-120{ }^{\circ} \mathrm{C} / 10-20 \mathrm{~min}\right)$, UHT $\left(135-140{ }^{\circ} \mathrm{C} / 6-10 \mathrm{~s}\right.$ for indirect and $140-150{ }^{\circ} \mathrm{C} / 2-4 \mathrm{~s}$ for direct UHT), or ISI $\left(150-200{ }^{\circ} \mathrm{C} /<0.1 \mathrm{~s}\right)$ treatments destroy vegetative as well as most sporulating pathogens [9], but high temperatures can cause detrimental effects on milk attributes [9].

Currently, there is a trend to consume raw milk based on the idea that heat destroys the nutritional and health benefits of milk [10]. The consumer demand for raw milk occurs from perceptions of better sensory and nutritional qualities of raw milk over those of pasteurized milk, besides the desire of many consumers to support local and small-scale agriculture [11,12]. It is important to observe that epidemiological data have demonstrated microbiological health risks associated with raw milk consumption [13]. This enforces the necessity of raw milk consumption being accompanied by a risk of ingesting pathogenic bacteria, which pose an elevated health hazard [14].

In the dairy industry, many problems associated with L. monocytogenes contamination are related to minimally processed or postpasteurization contamination from plant environments [15-17]. L. monocytogenes is a Gram-positive, rod-shaped, non-spore-forming, and facultative anaerobe bacterium [18]. It is widespread in the environment, and control of Listeria in food production facilities requires constant focus by risk managers [19].

L. monocytogenes is an important pathogenic bacterium for humans and animals, and causes public health problems [20]. L. monocytogenes is also a transitory resident of the intestinal tract in humans, with $2 \%-10 \%$ of the hosts not presenting any apparent health consequences [19]. Although rare, listerial contamination of dairy products can cause listeriosis, a serious illness [21]. The pasteurization of raw milk does not eliminate further risks of dairy product contamination by L. monocytogenes [22]. In addition, the presence of L. monocytogenes in food has important economic consequences, such as the withdrawal of products from the consumer marketplace and a decrease in sales of the incriminated products [23].

To meet the consumer demand for fresher-tasting minimally processed foods, the use of nonthermal technologies such as pulsed electric fields (PEFs) and high hydrostatic pressure (HHP) is on the frontline of the "emerging high-potential technologies for tomorrow" [24]. HHP has emerged [25] as a new preservation method to control, slow, and prevent the growth of foodborne pathogens, therefore extending shelf life with high energy efficiency and minimal food processing [26]. Postprocessing contamination is considerably reduced, as HHP technology can be applied to prepackaged products $[27,28]$. The combination of PEF with thermal treatment can have a beneficial use in improving microbial inactivation [29]. PEF processing of foods involves applying high-voltage electric fields $(5-80 \mathrm{kV} / \mathrm{cm})$ of short electric pulses $(1-100 \mu \mathrm{s})$ to a product hosted in a treatment chamber in either batch or continuous mode [30]. Therefore, the objective of this review is to describe the occurrence of L. monocytogenes in milk and advances in new nonthermal inactivation techniques published in the last 10 years (2008-present).

\section{Occurrence of L. monocytogenes in Fluid Milk}

L. monocytogenes has been detected in milk from several countries, with incidences varying from $0 \%$ to $50 \%$, as presented in Table 1 . In America, all samples have been from raw milk and from cow milk. Values in the United States have varied from 0\% to 19.7\%, and in South America values have been lower and have varied from $0 \%$ to $3.7 \%$. In Europe, the values have varied from $0 \%$ to $28.6 \%$. Most of the studies have used analyzed raw milk, but one in Austria analyzed pasteurized milk and found $0.0 \%$ of samples contaminated. In Italy, the sale of raw milk for human consumption in vending machines has been allowed since 2004 [31]. The same authors did two large surveys and found incidences of $0.54 \%$ and $0.1 \%$ of L. monocytogenes in raw milk [31,32]. 
Table 1. Worldwide occurrence of Listeria monocytogenes in milk.

\begin{tabular}{|c|c|c|c|c|}
\hline Country & Type of Milk & Samples Analyzed $(N)$ & Positive Samples $n(\%)$ & Reference \\
\hline \multicolumn{5}{|l|}{ America: } \\
\hline Brazil & Raw cow milk & 20 & $0(0.0 \%)$ & [33] \\
\hline Brazil & Pasteurized cow milk & 12 & $0(0.0 \%)$ & [33] \\
\hline Brazil & Raw goat milk & 53 & $0(0.0 \%)$ & [34] \\
\hline Brazil & Raw cow milk & 548 & $6(1.1 \%)$ & [35] \\
\hline Brazil & Raw cow milk & 210 & $0(0.0 \%)$ & [36] \\
\hline Brazil & Goat milk & 96 & $0(0.0 \%)$ & [37] \\
\hline Brazil & Raw cow milk & 36 & $0(0.0 \%)$ & [38] \\
\hline Brazil & Cow milk kept in cooler tank & 27 & $1(3.7 \%)$ & [39] \\
\hline Brazil & Raw cow milk & 165 & $0(0.0 \%)$ & [40] \\
\hline Colombia & Raw cow milk & 85 & $\begin{array}{c}13 \text { (16\%; traditional method) } \\
21 \text { (26\% Real Time-PCR) }\end{array}$ & [41] \\
\hline United States & $\begin{array}{l}\text { Raw cow milk } \\
\text { Raw goat milk } \\
\text { Raw sheep milk }\end{array}$ & $\begin{array}{c}12 \\
5 \\
4 \\
\end{array}$ & $0(0.0 \%)$ & [42] \\
\hline United States & Raw cow milk & 172 & $34(19.7 \%)$ & [12] \\
\hline United States & Raw cow milk & 1412 & $184(13.0 \%)$ & [43] \\
\hline United States & Raw cow milk & 536 & $24(4.5 \%)$ & [44] \\
\hline \multicolumn{5}{|l|}{ Europe: } \\
\hline Austria & Cow milk and products & 230 & $0(0.0 \%)$ & [45] \\
\hline Czech Republic & $\begin{array}{c}\text { Raw goat milk } \\
\text { Pasteurized goat milk }\end{array}$ & $\begin{array}{l}48 \\
40 \\
\end{array}$ & $0(0.0 \%)$ & [46] \\
\hline Czech Republic & Raw cow milk & 12 & $1(8.3 \%)$ & [47] \\
\hline Estonia & Raw cow milk & 14 & $4(28.6 \%)$ & [48] \\
\hline Estonia & Raw cow milk & 105 & $19(18.1 \%)$ & [49] \\
\hline Finland & Raw cow milk & 115 & $2(1.7 \%)$ & [13] \\
\hline Finland & Retailed raw cow milk bottles & 105 & $5(4.8 \%)$ & [13] \\
\hline Finland & Raw cow milk & 183 & $10(5.5 \%)$ & [50] \\
\hline Italy & Raw cow milk & 8716 & $145(1.7 \%)$ & [51] \\
\hline Italy & $\begin{array}{l}\text { Raw cow milk From vending } \\
\text { machines }\end{array}$ & 60,907 & $83(0.1 \%)$ & [52] \\
\hline Italy & $\begin{array}{l}\text { Raw cow milk From vending } \\
\text { machines }\end{array}$ & 15,264 & $83(0.54 \%)$ & [32] \\
\hline Italy & Raw cow milk & 27 & $1(3.7 \%)$ & [39] \\
\hline Portugal & Raw milk & 179 & $7(3.9 \%)$ & [52] \\
\hline Republic of Cyprus & Raw cow milk & 205 & $2(1.0 \%)$ & [53] \\
\hline Turkey & $\begin{array}{c}\text { Raw milk of: } \\
\text { Cow } \\
\text { Sheep } \\
\text { Goat }\end{array}$ & $\begin{array}{l}50 \\
75 \\
15\end{array}$ & $\begin{array}{l}1(2.0 \%) \\
2(2.7 \%) \\
0(0.0 \%)\end{array}$ & [54] \\
\hline Turkey & Raw cow milk & 175 & $1(0.6 \%)$ & [55] \\
\hline \multicolumn{5}{|l|}{ Africa: } \\
\hline Botswana & Raw cow milk & 278 & $3(1.1 \%)$ & [56] \\
\hline Egypt & Raw camel milk & 185 & $2(1.1 \%)$ & [57] \\
\hline Egypt & Raw cow milk & 30 & $0(0.0 \%)$ & [58] \\
\hline Egypt & Sheep and goat milk & $\begin{array}{l}102 \\
107\end{array}$ & $\begin{array}{l}1(0.9 \%) \\
2(1.9 \%)\end{array}$ & [59] \\
\hline Ethiopia & Raw cow milk & 60 & $2(3.4 \%)$ & [60] \\
\hline Ethiopia & $\begin{array}{c}\text { Raw cow milk } \\
\text { Pasteurized cow milk }\end{array}$ & $\begin{array}{l}50 \\
50\end{array}$ & $\begin{array}{l}2(4.0 \%) \\
0(0.0 \%)\end{array}$ & [61] \\
\hline Ethiopia & Raw cow milk & 100 & $22(22.0 \%)$ & [62] \\
\hline Ethiopia & Raw cow milk & 343 & $7(2.0 \%)$ & [63] \\
\hline Morocco & Raw cow milk & 96 & $8(8.33 \%)$ & [64] \\
\hline Morocco & Raw cow milk & 120 & $1(0.8 \%)$ & [65] \\
\hline Nigeria & Raw cow milk & 192 & $17(22.4 \%)$ & [66] \\
\hline \multicolumn{5}{|l|}{ Asia and Oceania: } \\
\hline China & Raw cow milk & 5211 & $19(0.36 \%)$ & [67] \\
\hline India & Raw cow milk & 2060 & $105(5.1 \%)$ & [68] \\
\hline India & Raw cow milk & 195 & $11(5.6 \%)$ & [69] \\
\hline India & Raw cow milk & 5 & $2(25.0 \%)$ & [1] \\
\hline India & Pasteurized milk & 5 & $0(0.0 \%)$ & [1] \\
\hline India & Raw cow milk & 50 & $3(6.0 \%)$ & [70] \\
\hline
\end{tabular}


Table 1. Cont.

\begin{tabular}{|c|c|c|c|c|}
\hline Country & Type of Milk & Samples Analyzed $(N)$ & Positive Samples $n(\%)$ & Reference \\
\hline India & Raw cow milk & 137 & $4(2.91 \%)$ & [71] \\
\hline India & Raw cow milk & 292 & $4(1.5 \%)$ & [72] \\
\hline India & Raw cow milk & 457 & $5(1.1 \%)$ & [73] \\
\hline India & $\begin{array}{c}\text { Raw cow milk } \\
\text { Pasteurized cow milk }\end{array}$ & $\begin{array}{c}120 \\
48\end{array}$ & $\begin{array}{c}7(5.8 \%) \\
0(0 \%)\end{array}$ & [74] \\
\hline Iran & Raw cow milk & 100 & $5(5.0 \%)$ & [75] \\
\hline Iran & Raw cow milk & 91 & $1(1.1 \%)$ & [76] \\
\hline Iran & Raw cow milk & 59 & $0(0 \%)$ & [77] \\
\hline Iran & Raw cow milk & 100 & $4(4.0 \%)$ & [78] \\
\hline Iran & Raw cow milk & 8 & $0(0 \%)$ & [79] \\
\hline Iran & $\begin{array}{l}\text { Raw cow milk } \\
\text { Raw sheep milk } \\
\text { Raw goat milk }\end{array}$ & $\begin{array}{c}240 \\
166 \\
41\end{array}$ & $\begin{array}{l}13(5.4 \%) \\
4(2.4 \%) \\
1(2.4 \%)\end{array}$ & [80] \\
\hline Iran & Raw cow milk & 120 & $3(2.5 \%)$ & [81] \\
\hline Iran & Raw cow milk & 18 & $9(50.0 \%)$ & [19] \\
\hline Iran & $\begin{array}{l}\text { Raw cow milk } \\
\text { Raw sheep milk } \\
\text { Raw goat milk } \\
\text { Raw camel milk }\end{array}$ & $\begin{array}{l}90 \\
62 \\
60 \\
48\end{array}$ & $\begin{array}{l}1(1.1 \%) \\
4(6.5 \%) \\
1(1.7 \%) \\
0(0.0 \%)\end{array}$ & [82] \\
\hline Iran & $\begin{array}{l}\text { Pasteurized cow milk } \\
\text { Raw cow milk }\end{array}$ & $\begin{array}{l}100 \\
100\end{array}$ & $0(0 \%)$ & [83] \\
\hline Iraq & $\begin{array}{c}\text { Raw cow milk } \\
\text { Raw sheep milk } \\
\text { Raw buffalo milk }\end{array}$ & $\begin{array}{l}100 \\
100 \\
100\end{array}$ & $\begin{array}{l}11(11.0 \%) \\
8(8.0 \%) \\
3(3.0 \%)\end{array}$ & [84] \\
\hline Jordan & Raw sheep milk & 165 & $19(11.5 \%)$ & [85] \\
\hline Syria & Raw cow milk & 766 & $35(4.6 \%)$ & [86] \\
\hline Uganda & Raw cow milk & 40 & $5(13 \%)$ & [87] \\
\hline New Zealand & Raw cow milk & 297 & $2(0.7 \%)$ & [7] \\
\hline
\end{tabular}

In African countries, L. monocytogenes incidence has varied from $0 \%$ to $22.0 \%$. Most samples have been from raw cow milk, but pasteurized cow milk, camel, sheep, and goat milk have also been analyzed. Only one study from New Zealand was found and is presented in this review. The authors recovered L. monocytogenes in 2 samples (0.7\%) of all 297 milk samples analyzed [6]. In the Middle East, L. monocytogenes incidence has varied from $0 \%$ to $50 \%$. Most samples have been from raw cow milk, but pasteurized cow milk, camel, sheep, buffalo, and goat milk have also been analyzed. It is important to observe that Reference [19] studied only 18 samples, but still the incidence of $9(50.0 \%)$ was very high. Finally, in Asia, L. monocytogenes incidence has varied from $0 \%$ to $25 \%$. It is also relevant to notice that Reference [1] analyzed only 5 raw milk samples, but still the incidence of $25 \%$ was high.

\section{Technological Approaches for Inactivation of L. monocytogenes in Fluid Milk}

Although traditional preservation processes (such as pasteurization and sterilization) are efficient in the production of microbiologically safe food, these processes result in degradations and undesirable changes in the nutritional (bioactive compounds, vitamins, and pigments) and sensory (texture, taste, flavor, and color) properties of foods, reducing their acceptability by consumers [88,89]. In this context, nonthermal emergent technologies (also known as mild processing methods) such as high pressure processing (HPP), high isostatic pressure (HIP) pulsed electric fields (PEFs), ultraviolet (UV) light (10-400 nm), and ultrasound (US) have been addressed with the objective of producing safe foods, reducing and eliminating these undesirable changes. Despite the advantages related to mild treatments, the main difficulties that limit the industrialization of these technologies are high costs, incomplete control of variable processes, and lack of regulatory approval. In addition, a study evaluating the acceptance of these products by consumers presented a crucial point for the commercial success of these technologies [90].

Table 2 shows the fundamentals, main principles, and mechanisms of inactivation of microorganisms in HPP, PEFs, UV, and US. According to Reference [90], nonthermal processes such as HPP, PEFs, and UV are the main promising technologies for the dairy sector. Hydrostatic 
high-pressure processing (HHPP) is a nonthermal technology applied to packaged foods, either solid or liquid. This technique has great potential to inactivate pathogenic and deteriorating microorganisms, producing microbiologically safe products with a long shelf life and with better nutritional and sensorial attributes [88]. The process basically consists of the application of isostatic pressures, transmitted uniformly and instantaneously to food. The isostatic principle ensures that the applied pressure and pressure within the food are equal, thus avoiding deformations in the food, for example [89].

Table 2. The fundamentals, main process parameters, and mechanisms of microbial inactivation by emergence nonthermal processes. PEFs: Pulsed electric fields; US: Ultrasound.

\begin{tabular}{|c|c|c|c|}
\hline Technologies & Fundamentals of Technology & Main Process Parameters & Main Mechanisms of Microbial Inactivation \\
\hline HIP & $\begin{array}{l}\text { Application of high isostatic } \\
\text { pressures }(100-1000 \mathrm{MPa}) \text { under } \\
\text { mild temperatures }\left(20-60^{\circ} \mathrm{C}\right)\end{array}$ & $\begin{array}{ll}- & \text { Pressure }(\mathrm{Mpa}) \\
- & \text { Temperature }\left({ }^{\circ} \mathrm{C}\right) \\
- & \text { Time }(\text { s or min })\end{array}$ & $\begin{array}{l}\text { Combinations of factors such as changes in cell membranes, } \\
\text { increased cell wall permeability, and leakage of intracellular } \\
\text { material, phospholipid crystallization, protein denaturation, } \\
\text { and destruction of vital complexes [88] }\end{array}$ \\
\hline PEFs & $\begin{array}{l}\text { Application of high intensities of } \\
\text { pulsed electric fields }(5-80 \mathrm{kV} / \mathrm{cm}) \\
\text { for a short time }(\mathrm{s} \text { or } \mathrm{ms}) \text { under } \\
\text { mild temperatures }\left(<50^{\circ} \mathrm{C}\right)\end{array}$ & $\begin{array}{ll}- & \text { Electric Field }(\mathrm{kV} / \mathrm{cm}) \\
- & \text { Pulse waveform } \\
- & \text { Exponential and square } \\
& \text { wave (mono or bipolar) } \\
- & \text { Pulse width }(\mathrm{ms}) \\
- & \text { Temperature }\left({ }^{\circ} \mathrm{C}\right) \\
- & \text { Time }(\mathrm{ms} \text { or } \mu \mathrm{s})\end{array}$ & $\begin{array}{l}\text { Induction of electroporation in microbial cells, which changes } \\
\text { membrane permeability (temporarily or permanently), } \\
\text { resulting in intracellular material extravasation and losses in } \\
\text { cell viability [89] }\end{array}$ \\
\hline UV & $\begin{array}{l}\text { Application of an electromagnetic } \\
\text { spectrum with wavelengths } \\
\text { between } 100 \text { and } 400 \mathrm{~nm}\end{array}$ & $\begin{array}{ll}- & \text { UV dose }\left(\mathrm{mJ} / \mathrm{cm}^{2}\right) \\
- & \text { Wavelength }(\mathrm{nm}) \\
- & \text { Power UV-lamp }(\mathrm{W})\end{array}$ & $\begin{array}{l}\text { Formation of lesions in the genomic DNA of organisms, by } \\
\text { UV-B and UV-C radiation, inhibiting DNA replication [89] }\end{array}$ \\
\hline
\end{tabular}

PEF technology consists of the application of pulsed electric fields of high intensities $(5-80 \mathrm{kV} / \mathrm{cm})$ for short periods of time (ms or $\mu \mathrm{s})$, with the potential to pasteurize liquid foods in mild temperatures $\left(<50^{\circ} \mathrm{C}\right)$. This treatment can be an alternative to traditional thermal processes such as pasteurization, because it presents efficiently in the inactivation of pathogenic microorganisms and some enzymes, maintaining the nutritional and sensory properties of the product. The efficiency of the process depends on several factors, such as electric field strength, treatment time, food temperature, and type of microorganism or enzyme [88,89]. Another promising technology for the dairy industry is ultraviolet (UV) light, which consists of the application of the electromagnetic spectrum, which has wavelengths between 100 and $400 \mathrm{~nm}$. UV light is divided into three regions: Short-wave ultraviolet (UV-C) from 200 to $280 \mathrm{~nm}$, UV-wave (UV-B) from 280 to $320 \mathrm{~nm}$, and UV-wave (UV-A) from 320 to $400 \mathrm{~nm}$. This technology promotes lesions in the genomic DNA of organisms, inhibiting DNA replication and consequently resulting in the inactivation of the microorganisms. Due to the high presence of suspended solids (such as proteins, fats), UV-light has limited penetration depth in milk. Therefore, to avoid subprocessing, one must work with thin films or capillaries, thus avoiding the application in large volumes of the product $[88,89,91]$.

Ultrasound (US) is a technique that uses high-power soundwaves (about $20 \mathrm{kHz}$ ). If the amplitude of the ultrasonic wave is high enough, cavitation will occur, which is the formation and breaking of microscopic bubbles. When the bubbles explode, shock waves are generated, promoting the generation of high temperatures and pressures, resulting in the inactivation of the microorganisms. The effects of cavitation on microbial suspensions include dispersion of microbial agglomerates, puncturing of the cell wall, modification of cellular activity, and greater sensitivity to heat. The main processing parameters are power, frequency, and treatment time. In addition to the advantage of maintaining the nutritional and sensory compounds of the product, US promotes the homogenization of milk fats, removes gases, and can better antioxidant activity [92]. 
A recent study applying US technology in semi-skimmed sheep milk proposed that the parameters tested were promising in achieving bacterial inactivation, eliminating or maintaining low-temperature processing, which is acceptable for drinking milk. The findings presented showed similar bacterial inactivation when US-treated milk was compared to conventional pasteurization, with the advantage of using small temperature processing. In addition, no relevant change was noted on protein or free amino acid profiles of pasteurized or US-treated semi-skimmed sheep milk, proving the technology could be used in milk to produce sheep milk products such as cheeses, maintaining the product quality [93].

Each of these emerging technologies has a specific mechanism of microbial inactivation, and its knowledge is of primary importance for the development of the technique and for the production of safe food. Thus, an understanding of the mechanisms and factors that affect microbial inactivation is of fundamental importance to ensure the microbiological safety of food. In general, most studies involving inactivation of pathogens by mild technologies have been based on the inactivation of Listeria spp. This may reflect major concerns about the potential presence of L. monocytogenes, mainly because several foods treated by these technologies require storage at low temperatures, which does not impair the growth of L. monocytogenes [93]. Several studies have used Listeria innocua as a surrogate of L. monocytogenes for the determination of kinetic parameters in mild treatments [88,94-96].

Regarding the kinetics of microbial inactivation by these technologies, possible deviations from linearity by some processes may be observed, with very relevant practical implications. To solve this problem, mathematical models (predictive models) are necessary to describe the kinetic parameters of the survival curve. The most-used nonlinear predictive models are the Weibull, log-logistic, Baranyi, and Gompertz models, which can be used through software such as GINAFit and DMFit. A detailed review of the models, as well as the definition of the estimated parameters, can be found in the literature [97-99]. Table 3 shows the kinetics of microbial inactivation of L. monocytogenes emerging in the milk during the different treatments.

Several factors may affect the resistance of pathogens such as L. monocytogenes in emerging nonthermal processes. According to Reference [89], these factors can be divided into factors that act before (physiological state of the microbial cells), during (product parameters and processing factors), and after (recovery conditions) treatment. This last factor (recovery conditions) presents a great challenge for the production of safe food by mild treatments. The presence of damaged cells due to sublethal inactivation during treatment may allow the microorganisms to repair sublethal damage and redevelop in the food, if they find adequate environmental conditions for their growth. This fact demonstrates the importance of evaluating the robustness of the formulations through challenge tests and the development of combined processes based on the use of these technologies together with additional preservation agents (hurdles) capable of interfering with the maintenance of cellular homeostasis $[88,89]$. Therefore, the determination of microbial inactivation parameters and the recovery conditions of injured microorganisms are crucial factors for the development and definition of process parameters for safe food production.

L. monocytogenes may be present in several places in the dairy environment, with contamination sources such as dairy ingredients or due to ineffective cleaning and sanitation, poor design or condition of food equipment or environment, or insufficient controls in the dairy factory [19]. The use of raw milk is often cited as a major factor for the contamination of L. monocytogenes in dairy products. However, this approach is very elementary. In this sense, to understand the survival of L. monocytogenes in dairy products during processing, challenge tests can be performed, which means the inoculation of the pathogen during the processing and testing its growth, which can determine the point at which the growth reaches unacceptable levels in a specific product [100]. The use of quantitative food microbiology tools, such as predictive microbiology, constitutes an interesting approach and should be encouraged for the dairy industry, mainly to establish the protective role of lactic bacteria regarding the survival and growth of L. monocytogenes in dairy products [101]. A recent study reported the presence of indigenous lactic bacteria with antilisterial activity in artisanal cheese [102], and future challenges 
include the study of their behavior in the processing and ripening of these products to increase safety for consumers.

Table 3. Recent studies on nonthermal technologies for the inactivation of L. monocytogenes in milk. HHP: High hydrostatic pressure.

\begin{tabular}{|c|c|c|c|c|c|c|}
\hline \multirow{2}{*}{ Type of Milk } & \multirow{2}{*}{ Technologies } & \multicolumn{3}{|c|}{ Operational Parameters } & \multirow{2}{*}{$\begin{array}{l}\text { Reduction Effect }\left(n=\log _{10}\right) \\
\text { or Inactivation Kinetics } * *\end{array}$} & \multirow{2}{*}{ References } \\
\hline & & Doses* & Time (unit) & Temperature $\left({ }^{\circ} \mathrm{C}\right)$ & & \\
\hline Whole Raw Milk & HHP & $300-600 \mathrm{MPa}$ & $1-105$ (min) & 25 & $\begin{aligned} D_{300 \mathrm{MPa}} & =10.99 \mathrm{~min} \\
D_{400 \mathrm{MPa}} & =6.00 \mathrm{~min} \\
D_{600 \mathrm{Mpa}} & =2.43 \mathrm{~min}\end{aligned}$ & [103] \\
\hline Human milk & HHP & $400 \mathrm{MPa}$ & $0-50(\min )$ & 31 & $n=8.0 \log _{10}(2 \mathrm{~min})$ & [104] \\
\hline Raw milk & HHP & $150-400 \mathrm{MPa}$ & $10-120$ (min) & 25 & $\begin{array}{l}D_{150 \mathrm{MPa}}=84.4 \mathrm{~min} \\
D_{250 \mathrm{MPa}}=46.0 \mathrm{~min} \\
D_{300 \mathrm{MPa}}=26.6 \mathrm{~min} \\
D_{350 \mathrm{MPa}}=13.9 \mathrm{~min}\end{array}$ & [105] \\
\hline Whole milk & HHPP & $300-500 \mathrm{MPa}$ & $<10(\min )$ & 30 & $D_{300 \mathrm{MPa}}=9.56 \mathrm{~min}$ & [106] \\
\hline UHT whole milk & НHРP & $400-600 \mathrm{MPa}$ & $0-30$ (min) & $27-60$ & $\begin{array}{c}D_{400 \mathrm{MPa} / 27^{\circ} \mathrm{C}}=592.1 \mathrm{~s} \\
D_{400 \mathrm{MPa} / 43^{\circ} \mathrm{C}}=238.4 \mathrm{~s} \\
D_{400 \mathrm{MPa} / 60^{\circ} \mathrm{C}}=15.4 \mathrm{~s} \\
D_{500 \mathrm{MPa} / 27^{\circ} \mathrm{C}}=75.5 \mathrm{~s} \\
D_{500 \mathrm{MPa} / 43^{\circ} \mathrm{C}}=52.7 \mathrm{~s} \\
D_{600 \mathrm{MPa} / 27^{\circ} \mathrm{C}}=19 \mathrm{~s} \\
D_{600 \mathrm{MPa} / 43^{\circ} \mathrm{C}}=12 \mathrm{~s}\end{array}$ & [107] \\
\hline UHT whole milk & HНPP & $350-600 \mathrm{MPa}$ & $0-40(\min )$ & 25 & $\begin{aligned} D_{350 \mathrm{MPa}} & =14.53 \mathrm{~min} \\
D_{450 \mathrm{MPa}} & =7.71 \mathrm{~min} \\
D_{550 \mathrm{MPa}} & =2.05 \mathrm{~min} \\
D_{600 \mathrm{MPa}} & =1.46 \mathrm{~min}\end{aligned}$ & [108] \\
\hline Milk & HHPP & $345 \mathrm{MPa}$ & $5(\mathrm{~min})$ & 50 & $n>8 \log _{10}$ & [109] \\
\hline Milk & HHPP & $550 \mathrm{Mpa}$ & $5(\mathrm{~min})$ & 25 & $n \sim 7 \log _{10}$ & [110] \\
\hline $\begin{array}{l}\text { Whole (W), } \\
\text { low-fat (LF) and } \\
\text { skim (S) milk }\end{array}$ & PEF & $\begin{array}{l}25-35 \mathrm{kV} / \mathrm{cm} ; 1700 \mathrm{~Hz} ; \\
1.5 \mu \mathrm{s} ; \text { (square waves) }\end{array}$ & $100-600(\mu \mathrm{s})$ & $10-50$ & $\begin{array}{c}n \sim 2.5 \log _{10}(\mathrm{~W}, \mathrm{LF}, \mathrm{S} ; 30 \\
\left.\mathrm{kV} / \mathrm{cm} ; 600 \mu \mathrm{ss} 25^{\circ} \mathrm{C}\right) \\
n \sim 4 \log _{10}(\mathrm{~W}, 30 \mathrm{kV} / \mathrm{cm} ; \\
\left.600 \mu \mathrm{s} 50^{\circ} \mathrm{C}\right) \\
n \sim 3 \log _{10}(\mathrm{~W}, 30 \mathrm{kV} / \mathrm{cm} ; \\
\left.300 \mu \mathrm{s} 50^{\circ} \mathrm{C}\right) \\
n n \sim 1.5 \log _{10}(\mathrm{~W}, 30 \mathrm{kV} / \mathrm{cm} ; \\
\left.300 \mu \mathrm{s} 25^{\circ} \mathrm{C}\right) \\
\end{array}$ & [111] \\
\hline Milk & PEF & $\begin{array}{c}15-30 \mathrm{kV} / \mathrm{cm} ; 200 \mathrm{~Hz} ; 2 \mu \mathrm{s} \\
\text { (square waves) }\end{array}$ & $0-600(\mu \mathrm{s})$ & $<35$ & $\begin{array}{c}n \sim 1 \log _{10}(15 \mathrm{kV} / \mathrm{cm} ; \\
200 \mu \mathrm{s}) \\
n \sim 2.1 \log _{10}(25 \mathrm{kV} / \mathrm{cm} ; \\
200 \mu \mathrm{s}) \\
n \sim 3.5 \log _{10}(30 \mathrm{kV} / \mathrm{cm} ; \\
200 \mu \mathrm{s}) \\
n \sim 5.2 \log _{10}(30 \mathrm{kV} / \mathrm{cm} ; \\
600 \mu \mathrm{s})\end{array}$ & [112] \\
\hline Sweet whey & PEF & $\begin{array}{l}25 \mathrm{kV} / \mathrm{cm} ; 1000 \mathrm{~Hz} ; 3 \mu \mathrm{s} \\
\text { (bipolar waves) }\end{array}$ & $48(\mu \mathrm{s})$ & 23 & $n \sim 1.8-3.6 \log _{10} * * *$ & [94] \\
\hline Skim milk & PEF & $15-30 \mathrm{kV} / \mathrm{cm} ; 3.25 \mu \mathrm{s}$ & $5-50(\mu \mathrm{s})$ & $0-60$ & $\begin{array}{c}n \sim 0.75 \log _{10}(30 \mathrm{kV} / \mathrm{cm} ; \\
\left.10 \mu \mathrm{ss} 35^{\circ} \mathrm{C}\right) \\
n \sim 0.85 \log _{10}(20 \mathrm{kV} / \mathrm{cm} ; \\
\left.50 \mu \mathrm{s} ; 35^{\circ} \mathrm{C}\right) \\
n \sim 4.5 \log _{10}(20 \mathrm{kV} / \mathrm{cm} ; \\
\left.10 \mu \mathrm{s} ; 55^{\circ} \mathrm{C}\right)\end{array}$ & [113] \\
\hline Milk & US & $20 \mathrm{kHz} ; 750 \mathrm{~W} ; 124 \mu \mathrm{m}$ & $2.5-10(\mathrm{~min})$ & $<26$ & $\begin{array}{c}D_{750 \mathrm{~W}}=5.1 \mathrm{~min} \\
n \sim 2 \log _{10}(10 \mathrm{~min})\end{array}$ & [92] \\
\hline $\begin{array}{l}\text { Nonfat; low-fat; } \\
\text { whole milk }\end{array}$ & US & $28-100 \mathrm{kHz}^{* *} ; 600 \mathrm{~W}$ & 50 (min) & $60(\max )$ & $\begin{array}{l}D_{600 \mathrm{~W}}=3.22 \mathrm{~min} \text { (nonfat) } \\
D_{600 \mathrm{~W}}=2.71 \mathrm{~min} \text { (low-fat) } \\
D_{600 \mathrm{~W}}=4.24 \mathrm{~min} \text { (whole) }\end{array}$ & [114] \\
\hline $\begin{array}{l}\text { Whole (W), skim } \\
\text { (S) milk }\end{array}$ & US & $24 \mathrm{kHz} ; 100 \mu \mathrm{m}$ & $50(\min )$ & $<35$ & $\begin{array}{l}D=9.31 \min (\mathrm{W}) \\
D=8.61 \min (\mathrm{S})\end{array}$ & [115] \\
\hline Skim milk & UV Light & $0-40 \mathrm{~mJ} / \mathrm{cm}^{2}$ & NI & 22 & $\begin{array}{c}n=5 \log _{10}\left(20 \mathrm{~mJ} / \mathrm{cm}^{2}\right) \\
D=2.46 \mathrm{~mJ} / \mathrm{cm}^{2}\end{array}$ & [116] \\
\hline Raw goat milk & UV Light & $0-20 \mathrm{~mJ} / \mathrm{cm}^{2}$ & NI & NI & $n=5 \log _{10}\left(15.8 \mathrm{~mJ} / \mathrm{cm}^{2}\right)$ & [117] \\
\hline $\begin{array}{l}\text { Human breast } \\
\text { milk }\end{array}$ & UV light & $0-5000 \mathrm{~mJ} / \mathrm{cm}^{2}$ & $0-60(\min )$ & NI & $\begin{array}{c}D_{630.51 \mathrm{~mJ} / \mathrm{cm}^{2}}=7.67 \mathrm{~min}{ }^{* * * *} ; \\
n=4.51 \log _{10}(60 \mathrm{~min})\end{array}$ & [118] \\
\hline Milk & UV Light & $21.3 \mathrm{~mJ} / \mathrm{cm}^{2}$ & 60 (min) & 25 & $n \sim 6 \log _{10}(60 \mathrm{~min})$ & [91] \\
\hline
\end{tabular}

* HPP (MPa); PEF (kV/cm; Hz; $\mu$; type of wave); US $(\mathrm{kHz} ; \mathrm{W} ; \mu \mathrm{m}) ; \mathrm{UV}-\mathrm{light}\left(\mathrm{mJ} / \mathrm{cm}^{2}\right) .{ }^{* *}$ Log cycles of L. monocytogenes reduction; $d$ is a scale parameter denoting the time for the first decimal reduction by Weibull models; $D=$ time required to reduce the number of survivors by $90 \%$. ${ }^{* * *}$ For nine species of L. monocytogenes. **** Ultrasonic oscillations where frequencies are switched between 28,45 , and $100 \mathrm{kHz}$ at 1-ms time intervals. NI: Not informed. NA: Not applied. UHT: Ultrahigh temperature. 
All of these topics should be tested, considering the intrinsic parameters involved with emerging technologies, to establish synergic actions among the conventional and heat treatments used in raw milk. It is important to emphasize that there are several protocols for manufacturing dairy foods, in particular typical or artisanal ones, hence indicating the necessity of continuous and strict studies to generate safe conclusions for each type of process.

\section{Conclusions and Future Trends}

The occurrence of L. monocytogenes is worldwide, and emerging technologies can be used for its inactivation and to guarantee the safety of processed products. Despite the development of technological approaches for the treatment of milk, the worldwide incidence of L. monocytogenes in milk for human consumption is still a public health concern. The problems associated with L. monocytogenes contamination in the dairy industry are related to minimally processed or postpasteurization contamination from plant environments due to this bacterium being widely spread in the environment and the difficult control constant focus by risk managers. Considering the current demand for minimally processed milk, the recent advances in nonthermal technologies, such as HHP, PEFs, US, and UV, have great potential for applications in milk processing plants aiming to reduce the health risks associated with contamination of milk from L. monocytogenes. However, more studies should be conducted concerning the inactivation kinetic determination to establish how the process conditions for microbiological safety should be done.

Author Contributions: Original draft preparation, S.H.I.L., C.H.C., and A.G.C.; literature search and data retrieval: S.H.I.L., L.P.C., J.T.G., C.F.B., and R.S.R.; review and editing, C.A.F.O., A.G.C., and L.T.F.

Acknowledgments: The authors thank the Conselho Nacional de Desenvolvimento Científico e Tecnológico (CNPq) for financial support and fellowship-Grant no. 306304/2017-1.

Conflicts of Interest: The authors declare no conflict of interest.

\section{References}

1. Muthulakshmi, K.; Uma, C.; Sivagurunathan, P. Occurrence of Listeria monocytogenes in milk and milk products. Int. J. Rec. Res. Life Sci. 2018, 7, 1572-1574.

2. Geigl, E.-M. Palaeogenetics of cattle domestication: Methodological challenges for the study of fossil bones preserved in the domestication centre in Southwest Asia. C. R. Palevol 2008, 7, 99-112. [CrossRef]

3. Bando, E.; Oliveira, R.C.; Ferreira, G.M.Z.; Machinski, M., Jr. Occurrence of antimicrobial residues in pasteurized milk commercialized in the state of Paraná, Brazil. J. Food Prot. 2009, 72, 911-914. [CrossRef] [PubMed]

4. Balthazar, C.F.; Pimentel, T.C.; Ferrão, L.L.; Almada, C.N.; Santillo, A.; Albenzio, M.; Mollakhalili, N.; Mortazavian, A.M.; Nascimento, J.S.; Silva, M.C.; et al. Sheep milk: Physicochemical characteristics and relevance for functional food development. Compr. Rev. Food Sci. 2017, 16, 247-262. [CrossRef]

5. Adams, M.R.; Moss, M.O. Food Microbiology; Royal Society of Chemistry: Cambridge, UK, 2008.

6. Amagliani, G.; Petruzzelli, A.; Omiccioli, E.; Tonucci, F; Magnani, M.; Brandi, G. Microbiological surveillance of a bovine raw milk farm through multiplex real-time PCR. Foodborne Pathog. Dis. 2012, 9, 406-411. [CrossRef] [PubMed]

7. Hill, B.; Smythe, B.; Lindsay, D.; Shepherd, J. Microbiology of raw milk in New Zealand. Int. J. Food Microbiol. 2012, 157, 305-308. [CrossRef] [PubMed]

8. Headrick, M.L.; Korangy, S.; Bean, N.H.; Angulo, F.J.; Altekruse, S.F.; Potter, M.E.; Klontz, K.C. The epidemiology of raw milk-associated foodborne disease outbreaks reported in the United States, 1973 through 1992. Am. J. Public Health 1998, 88, 1219-1221. [CrossRef]

9. Martin, B.; Chamba, J.F.; Coulon, J.B.; Perreard, E. Effect of milk chemical composition and clotting characteristics on chemical and sensory properties of Reblochon de Savoie cheese. J. Dairy Res 1997, 64, 157-162. [CrossRef] 
10. Claeys, W.L.; Cardoen, S.; Daube, G.; De Block, J.; Dewettinck, K.; Dierick, K.; de Zutter, L.; Huyghebaert, A.; Imberechts, H.; Thiange, P.; et al. Raw or heated cow milk consumption: Review of risks and benefits. Food Control 2013, 31, 251-262. [CrossRef]

11. Perkiomäki, J.; Leimi, A.; Tuominen, P. Suomessa tuotetun raakamaidon biologiset vaarat-riskiprofiili. [Biological hazards of raw milk produced in Finland-risk profile]. Eviran tutkimuksia 2012, 4, 1-131.

12. Rahn, W.M.; Gollust, S.E.; Tang, X. Framing Food Policy: The Case of Raw Milk. Policy Stud. J. 2016. [CrossRef]

13. Castro, H.; Ruusunen, M.; Lindström, M. Occurrence and growth of Listeria monocytogenes in packaged raw milk. Int. J. Food Microbiol. 2017, 261, 1-10. [CrossRef] [PubMed]

14. Latorre, A.A.; Van Kessel, J.A.S.; Karns, J.S.; Zurakowski, M.J.; Pradhan, A.K.; Zadoks, R.N.; Boor, K.J.; Schukken, Y.H. Molecular ecology of Listeria monocytogenes: Evidence for a reservoir in milking equipment on a dairy farm. Appl. Environ. Microbiol 2009, 75, 1315-1323. [CrossRef] [PubMed]

15. Gougouli, M.; Angelidis, A.S.; Koutsoumanis, K. A study on the kinetic behavior of Listeria monocytogenes in ice cream stored under static and dynamic chilling and freezing conditions. J. Dairy Sci. 2008, 91, 523-530. [CrossRef] [PubMed]

16. Rosshaug, P.S.; Detmer, A.; Ingmer, H.; Larsen, M.H. Modeling the growth of Listeria monocytogenes in soft blue-white cheese. Appl. Environ. Microbiol. 2012, 78, 8508-8514. [CrossRef] [PubMed]

17. Olszewska, M.A.; Panfil-Kuncewicz, H.; Łaniewska-Trokenheim, L. Detection of viable but nonculturable cells of L. monocytogenes with the use of directepifluorescent filter technique. J. Food Saf. 2015, 35, 86-90. [CrossRef]

18. Sukhadeo, B.B.; Trinad, C. Molecular mechanisms of bacterial infection via the gut. Curr. Top. Microbiol. Immunol. 2009, 337, 173-195.

19. Buchanan, R.L.; Gorris, L.G.; Hayman, M.M.; Jackson, T.C.; Whiting, R.C. A review of Listeria monocytogenes: An update on outbreaks, virulence, dose-response, ecology, and risk assessments. Food Control 2017, 75, 1-13. [CrossRef]

20. Moosavy, M.H.; Esmaeili, S.; Mostafavi, E.; Amiri, F.B. Isolation of Listeria monocytogenes from milks used for Iranian traditional cheese in Lighvan cheese factories. Ann. Agric. Environ. Med. 2014, 21, 728-729. [CrossRef]

21. Davis, B.J.; Li, C.X.; Nachman, K.E. A Literature Review of the Risks and Benefits of Consuming Raw and Pasteurized Cow's Milk; A Response to the Request from The Maryland House of Delegates' Health and Government Operations Committee; John Hopkins Report; Johns Hopkins University: Baltimore, MD, USA, 2014.

22. Gould, L.H.; Walsh, K.A.; Vieira, A.R.; Herman, K.; Williams, I.T.; Hall, A.J.; Cole, D. Surveillance for foodborne disease outbreaks-United States, 1998-2008. MMWR CDC Surveill. Summ. 2013, 62, 1-34.

23. Auvolat, A.; Besse, N.G. The challenge of enumerating Listeria monocytogenes in food. Food Microbiol. 2016, 53, 135-149. [CrossRef] [PubMed]

24. De Vries, H.; Mikolajczak, M.; Salmon, J.M.; Abecassis, J.; Chaunier, L.; Guessasma, S.; Trystram, G. Small-Scale Food Process Engineering-Challenges and Perspectives. Innov. Food Sci. Emerg. Technol. 2017. [CrossRef]

25. Norton, T.; Sun, D.W. Recent advances in the use of high pressure as an effective processing technique in the food industry. Food Bioprocess Technol. 2008, 1, 2-34. [CrossRef]

26. Tomasula, P.M.; Renye, J.A.; Van Hekken, D.L.; Tunick, M.H.; Kwoczak, R.; Toht, M.; Leggett, L.N.; Luchansky, J.B.; Porto-Fett, A.C.S.; Phillips, J.G. Effect of high-pressure processing on reduction of Listeria monocytogenes in packaged Queso Fresco. J. Dairy Sci. 2014, 97, 1281-1295. [CrossRef] [PubMed]

27. Patterson, M.F. Microbiology of pressure-treated foods. J. Appl. Microbiol. 2005, 98, 1400-1409. [CrossRef]

28. Ye, M.; Huang, Y.; Gurtler, J.B.; Niemira, B.A.; Sites, J.E.; Chen, H. Effects of preor post-processing storage conditions on high-hydrostatic pressure inactivation of Vibrio parahaemolyticus and V. vulnificus in oysters. Int. J. Food Microbiol. 2013, 163, 146-152. [CrossRef] [PubMed]

29. Guerrero-Beltrán, J.Á.; Sepulveda, D.R.; Góngora-Nieto, M.M.; Swanson, B.; Barbosa-Cánovas, G.V. Milk thermization by pulsed electric fields (PEF) and electrically induced heat. J. Food Eng. 2010, 100, 56-60. [CrossRef]

30. Caminiti, I.M.; Palgan, I.; Noci, F.; Muñoz, A.; Whyte, P.; Cronin, D.A.; Morgan, D.J.; Lyng, J.G. The effect of pulsed electric fields (PEF) in combination with high intensity light pulses (HILP) on Escherichia coli inactivation and quality attributes in apple juice. Innov. Food Sci. Emerg. Technol. 2011, 12, 118-123. [CrossRef] 
31. Giacometti, F.; Bonilauri, P.; Serraino, A.; Peli, A.; Amatiste, S.; Arrigoni, N.; Bianchi, M.; Bilei, S.; Cascone, G.; Comin, D.; et al. Four-year monitoring of foodborne pathogens in raw milk sold by vending machines in Italy. J. Food Prot. 2013, 76, 1902-1907. [CrossRef]

32. Giacometti, F.; Bonilauri, P.; Albonetti, S.; Amatiste, S.; Arrigoni, N.; Bianchi, M.; Bertasi, B.; Bilei, S.; Bolzoni, G.; Cascone, G.; et al. Quantitative risk assessment of human salmonellosis and listeriosis related to the consumption of raw milk in Italy. J. Food Prot. 2015, 78, 13-21. [CrossRef]

33. Barancelli, G.V.; Camargo, T.M.; Reis, C.M.; Porto, E.; Hofer, E.; Oliveira, C.A. Incidence of Listeria monocytogenes in cheese manufacturing plants from the northeast region of São Paulo, Brazil. J. Food Prot. 2011, 74, 816-819. [CrossRef] [PubMed]

34. Cavicchioli, V.Q.; Scatamburlo, T.M.; Yamazi, A.K.; Pieri, F.A.; Nero, L.A. Occurrence of Salmonella, Listeria monocytogenes, and enterotoxigenic Staphylococcus in goat milk from small and medium-sized farms located in Minas Gerais State, Brazil. J. Dairy Sci. 2015, 98, 8386-8390. [CrossRef] [PubMed]

35. Cerva, C.; Bremm, C.; Dos Reis, E.M.; Bezerra, A.V.A.; Loiko, M.R.; da Cruz, C.E.F.; Cenci, A.; Mayer, F.Q. Food safety in raw milk production: Risk factors associated to bacterial DNA contamination. Trop. Anim. Health Prod. 2014, 46, 877-882. [CrossRef] [PubMed]

36. Nero, L.A.; De Mattos, M.R.; de Aguiar Ferreira Barros, M.; Ortolani, M.B.T.; Beloti, V.; de Melo Franco, B.D.G. Listeria monocytogenes and Salmonella spp. in raw milk produced in Brazil: Occurrence and interference of indigenous microbiota in their isolation and development. Zoonoses Public Health 2008, 55, 299-305. [CrossRef] [PubMed]

37. Oliveira, C.J.B.; Hisrich, E.R.; Moura, J.F.P.; Givisiez, P.E.N.; Costa, R.G.; Gebreyes, W.A. On farm risk factors associated with goat milk quality in Northeast Brazil. Small Rumin. Res. 2011, 98, 64-69. [CrossRef]

38. Ortolani, M.B.T.; Yamazi, A.K.; Moraes, P.M.; Viçosa, G.N.; Nero, L.A. Microbiological quality and safety of raw milk and soft cheese and detection of autochthonous lactic acid bacteria with antagonistic activity against Listeria monocytogenes, Salmonella spp., and Staphylococcus aureus. Foodborne Pathog. Dis. 2010, 7, 175-180. [CrossRef] [PubMed]

39. Parisi, A.; Latorre, L.; Fraccalvieri, R.; Miccolupo, A.; Normanno, G.; Caruso, M.; Santagada, G. Occurrence of Listeria spp. in dairy plants in Southern Italy and molecular subtyping of isolates using AFLP. Food Control 2013, 29, 91-97. [CrossRef]

40. Costa Sobrinho, P.D.S.; Marcal de Faria, C.A.; Silva Pinheiro, J.; Gonçalves de Almeida, H.; Vieira Pires, C.; Silva Santos, A. Bacteriological quality of raw milk used for production of a Brazilian farmstead raw milk cheese. Foodborne Pathog. Dis. 2012, 9, 138-144. [CrossRef]

41. Vanegas, M.C.; Vásquez, E.; Martinez, A.J.; Rueda, A.M. Detection of Listeria monocytogenes in raw whole milk for human consumption in Colombia by real-time PCR. Food Control 2009, 20, 430-432. [CrossRef]

42. D'Amico, D.J.; Donnelly, C.W. Detection, isolation, and incidence of Listeria spp. in small-scale artisan cheese processing facilities: A methods comparison. J. Food Prot. 2009, 72, 2499-2507. [CrossRef]

43. Mohammed, H.O.; Stipetic, K.; McDonough, P.L.; Gonzalez, R.N.; Nydam, D.V.; Atwill, E.R. Identification of potential on-farm sources of Listeria monocytogenes in herds of dairy cattle. Am. J. Vet. Res. 2009, 70, 383-388. [CrossRef] [PubMed]

44. Van Kessel, J.A.S.; Karns, J.S.; Lombard, J.E.; Kopral, C.A. Prevalence of Salmonella enterica, Listeria monocytogenes, and Escherichia coli virulence factors in bulk tank milk and in-line filters from US dairies. J. Food Prot. 2011, 74, 759-768. [CrossRef] [PubMed]

45. Schoder, D.; Melzner, D.; Schmalwieser, A.; Zangana, A.; Winter, P.; Wagner, M. Important vectors for Listeria monocytogenes transmission at farm dairies manufacturing fresh sheep and goat cheese from raw milk. J. Food Prot. 2011, 74, 919-924. [CrossRef] [PubMed]

46. Cupáková, Š.; Pospíšilová, M.; Karpíšková, R.; Janštová, B.; Vorlová, L. Microbiological quality and safety of goat's milk from one farm. Acta Univ. Agric. Silvic. Mendel. Brun. 2013, 60, 33-38. [CrossRef]

47. Roubal, P.; JagliC, Z. Microbial contamination after sanitation of food contact surfaces in dairy and meat processing plants. Czech J. Food Sci. 2010, 28, 450-461.

48. Kalmus, P.; Kramarenko, T.; Roasto, M.; Meremäe, K.; Viltrop, A. Quality of raw milk intended for direct consumption in Estonia. Food Control 2015, 51, 135-139. [CrossRef]

49. Kramarenko, T.; Roasto, M.; Meremäe, K.; Kuningas, M.; Põltsama, P.; Elias, T. Listeria monocytogenes prevalence and serotype diversity in various foods. Food Control 2013, 30, 24-29. [CrossRef] 
50. Ruusunen, M.; Salonen, M.; Pulkkinen, H.; Huuskonen, M.; Hellström, S.; Revez, J.; Hänninen, M.L.; Fredriksson-Ahomaa, M.; Lindström, M. Pathogenic bacteria in Finnish bulk tank milk. Foodborne Pathog. Dis. 2013, 10, 99-106. [CrossRef] [PubMed]

51. Dalzini, E.; Bernini, V.; Bertasi, B.; Daminelli, P.; Losio, M.N.; Varisco, G. Survey of prevalence and seasonal variability of Listeria monocytogenes in raw cow milk from Northern Italy. Food Control 2016, 60, 466-470. [CrossRef]

52. Almeida, G.; Magalhães, R.; Carneiro, L.; Santos, I.; Silva, J.; Ferreira, V.; Hogg, T.; Teixeira, P. Foci of contamination of Listeria monocytogenes in different cheese processing plants. Int. J. Food. Microbiol 2013, 167, 303-309. [CrossRef] [PubMed]

53. Botsaris, G.; Nikolaou, K.; Liapi, M.; Pipis, C. Prevalence of Listeria spp. and Listeria monocytogenes in cattle farms in Cyprus using bulk tank milk samples. J. Food Saf. 2016, 36, 482-488. [CrossRef]

54. Durmaz, H.; Avc1, M.; Aygün, O. The presence of Listeria species in corn silage and raw milk produced in Southeast region of Turkey. Kafkas Univ. Vet. Fak. Derg. 2015, 21, 41-44.

55. Taşçi, F.; Türütoğlu, H.; Öğütçü, H. Investigations of Listeria species in milk and silage produced in Burdur province. Kafkas Üniversitesi Veteriner Fakültesi Dergisi 2010, 16, 93-97.

56. Morobe, I.C.; Obi, C.L.; Nyila, M.A.; Gashe, B.A.; Matsheka, M.I. Prevalence, antimicrobial resistance profiles of Listeria monocytogenes from various foods in Gaborone, Botswana. Afr. J. Biotechnol. 2009, 8, 6383-6387. [CrossRef]

57. Abeer, A.A.; Gouda, A.S.; Dardir, H.; Ibrahim, A. Prevalence of some milk borne bacterial pathogens threatening camel milk consumers in Egypt. Glob. Vet. 2012, 8, 76-82.

58. Ismaiel, A.A.R.; Ali, A.E.S.; Enan, G. Incidence of Listeria in Egyptian meat and dairy samples. Food Sci. Biotechnol. 2014, 23, 179-185. [CrossRef]

59. Osman, K.M.; Zolnikov, T.R.; Samir, A.; Orabi, A. Prevalence, pathogenic capability, virulence genes, biofilm formation, and antibiotic resistance of Listeria in goat and sheep milk confirms need of hygienic milking conditions. Pathog. Glob. Health 2014, 108, 21-29. [CrossRef]

60. Derra, F.A.; Karlsmose, S.; Monga, D.P.; Mache, A.; Svendsen, C.A.; Félix, B.; Granier, S.A.; Geyid, A.; Taye, G.; Hendriksen, R.S. Occurrence of Listeria spp. in retail meat and dairy products in the area of Addis Ababa, Ethiopia. Foodborne Pathog. Dis. 2013, 10, 577-579. [CrossRef]

61. Garedew, L.; Taddese, A.; Biru, T.; Nigatu, S.; Kebede, E.; Ejo, M.; Fikru, A.; Birhanu, T. Prevalence and antimicrobial susceptibility profile of Listeria species from ready-to-eat foods of animal origin in Gondar Town, Ethiopia. BMC Microbiol. 2015, 15, 100. [CrossRef]

62. Gebretsadik, S.; Kassa, T.; Alemayehu, H.; Huruy, K.; Kebede, N. Isolation and characterization of Listeria monocytogenes and other Listeria species in foods of animal origin in Addis Ababa, Ethiopia. J. Infect. Public Health 2011, 4, 22-29. [CrossRef]

63. Seyoum, E.T.; Woldetsadik, D.A.; Mekonen, T.K.; Gezahegn, H.A.; Gebreyes, W.A. Prevalence of Listeria monocytogenes in raw bovine milk and milk products from central highlands of Ethiopia. J. Infect. Dev. Ctries. 2015, 9, 1204-1209. [CrossRef] [PubMed]

64. El Marnissi, B.; Bennani, L.; Cohen, N.; Lalami, A.E.O.; Belkhou, R. Presence of Listeria monocytogenes in raw milk and traditional dairy products marketed in the north-central region of Morocco. Afr. J. Food Sci. 2013, 7, 87-91. [CrossRef]

65. Hadrya, F.; Elouardi, A.; Benali, D.; Hami, H.; Soulaymani, A.; Senouci, S. Bacterial quality of informally marketed raw milk in Kenitra city, Morocco. Pakistan J. Nutr. 2012, 11, 662-669. [CrossRef]

66. Yakubu, Y.; Salihu, M.D.; Faleke, O.O.; Abubakar, M.B.; Junaidu, A.U.; Magaji, A.A.; Gulumbe, M.L.; Aliyu, R.M. Prevalence and antibiotic susceptibility of Listeria monocytogenes in raw milk from cattle herds within Sokoto Metropolis, Nigeria. Sokoto J. Vet. 2012, 10. [CrossRef]

67. Ning, P.; Guo, K.; Cheng, L.; Xu, L.; Zhang, C.; Cui, H.; Cheng, Y.; Xu, R.; Liu, W.; Lv, Q.; et al. Pilot survey of raw whole milk in China for Listeria monocytogenes using PCR. Food Control 2013, 31, 176-179. [CrossRef]

68. Kalorey, D.R.; Warke, S.R.; Kurkure, N.V.; Rawool, D.B.; Barbuddhe, S.B. Listeria species in bovine raw milk: A large survey of Central India. Food Control 2008, 19, 109-112. [CrossRef]

69. Karthikeyan, R.; Gunasekaran, P.; Rajendhran, J. Molecular serotyping and pathogenic potential of Listeria monocytogenes isolated from milk and milk products in Tamil Nadu, India. Foodborne Pathog. Dis. 2015, 12, 522-528. [CrossRef] 
70. Nayak, D.N.; Savalia, C.V.; Kalyani, I.H.; Kumar, R.; Kshirsagar, D.P. Isolation, identification, and characterization of Listeria spp. from various animal origin foods. Vet. World 2015, 8, 695-701. [CrossRef]

71. Sarangi, L.N.; Panda, H.K.; Priyadarshini, A.; Sahoo, S.; Palai, T.K.; Ranabijuli, S.; Senapati, S.; Mohanty, D.N. Prevalence of Listeria species in milk samples of cattle of Odisha. Indian J. Comp. Microbiol. Immunol. Infect. Dis. 2009, 30, 135-136.

72. Shamloo, E.; Jalali, M.; Mirlohi, M.; Madani, G.; Metcalf, D.; Merasi, M.R. Prevalence of Listeria species in raw milk and traditional dairy products in Isfahan, Iran. Int. J. Environ. Health Eng. 2015, 4, 1.

73. Sharma, S.; Sharma, V.; Dahiya, D.K.; Khan, A.; Mathur, M.; Sharma, A. Prevalence, virulence potential, and antibiotic susceptibility profile of Listeria monocytogenes isolated from bovine raw milk samples obtained from Rajasthan, India. Foodborne Pathog. Dis. 2017, 14, 132-140. [CrossRef] [PubMed]

74. Soni, D.K.; Singh, R.K.; Singh, D.V.; Dubey, S.K. Characterization of Listeria monocytogenes isolated from Ganges water, human clinical and milk samples at Varanasi, India. Infect. Genet. Evol. 2013, 14, 83-91. [CrossRef] [PubMed]

75. Mansouri-Najand, L.; Kianpour, M.; Sami, M.; Jajarmi, M. Prevalence of Listeria monocytogenes in raw milk in Kerman, Iran. Vet. Res. Forum 2015, 6, 223-226. [PubMed]

76. Shamloo Aghakhani, E.; Jalali, M.; Mirlohi, M.; Abdi Moghadam, Z.; Shamloo Aghakhani, E.; Reza Maracy, M.; Yaran, M. Prevalence of Listeria species in raw milk in Isfahan, Iran. J. Isfahan Med. Sch. 2012, 30, 204.

77. Akya, A.; Najafi, F.; Moradi, J.; Mohebi, Z.; Adabagher, S. Prevalence of food contamination with Listeria spp. in Kermanshah, Islamic Republic of Iran. East. Mediterr. Health J. 2013, 19, 474-477. [CrossRef] [PubMed]

78. Jamshidi, A.; Khanzadi, S. The presence of Listeria monocytogenes in raw milk samples in Mashhad, Iran. Iran. J. Vet. Res. 2011, 11, 363-367.

79. Jalali, M.; Abedi, D. Prevalence of Listeria species in food products in Isfahan, Iran. Int. J. Food Microbiol. 2008, 122, 336-340. [CrossRef]

80. Jamali, H.; Radmehr, B.; Thong, K.L. Prevalence, characterization, and antimicrobial resistance of Listeria species and Listeria monocytogenes isolates from raw milk in farm bulk tanks. Food Control 2013, 34, 121-125. [CrossRef]

81. Mahmoodi, M.M. Occurrence of Listeria monocytogenes in raw milk and dairy products in Noorabad, Iran. J. Anim. Vet. Adv. 2010, 9, 16-19.

82. Rahimi, E.; Ameri, M.; Momtaz, H. Prevalence and antimicrobial resistance of Listeria species isolated from milk and dairy products in Iran. Food Control 2010, 21, 1448-1452. [CrossRef]

83. Vahedi, M.; Nasrolahei, M.; Sharif, M.; Mirabi, A.M. Bacteriological study of raw and unexpired pasteurized cow's milk collected at the dairy farms and super markets in Sari city in 2011. J. Prev. Med. Hyg. 2013, 54, 120-123. [PubMed]

84. Abbas, B.A.; Jaber, G.M. Occurrence of Listeria monocytogenes in raw milk of ruminants. Iraqi J. Vet. Sci. 2012, $26,47-51$.

85. Al-Tahiri, R.I.A.D.H.; Omar, S.; Rewashdeh, A. A study of the occurrence of Listeria species in raw sheep milk. Int. J. Dairy Technol. 2008, 61, 347-351. [CrossRef]

86. Al-Mariri, A.; Younes, A.; Ramadan, L. Prevalence of Listeria spp. in raw milk in Syria. Bulg. J. Vet. Med. 2013, 16, 112-122.

87. Mugampoza, D.; Muyanja, C.M.; Ogwok, P.; Serunjogi, M.L.; Nasinyama, G.W. Occurrence of Listeria monocytogenes in bulked raw milk and traditionally fermented dairy products in Uganda. Afr. J. Food Agric. Nutr. Dev. 2011, 11, 4610-4622. [CrossRef]

88. Barba, F.J.; Koubaa, M.; do Prado-Silva, L.; Orlien, V.; de Souza Sant'Ana, A. Mild processing applied to the inactivation of the main foodborne bacterial pathogens: A review. Trends Food Sci. Technol. 2017, 66, $20-35$. [CrossRef]

89. Cebrian, G.; Manas, P.; Condon, S. Comparative resistance of bacterial foodborne pathogens to non-thermal technologies for food preservation. Front. Microbiol. 2016, 7, 734. [CrossRef]

90. Jermann, C.; Koutchma, T.; Margas, E.; Leadley, C.; Ros-Polski, V. Mapping trends in novel and emerging food processing technologies around the world. Innov. Food Sci. Emerg. Technol. 2015, 31, 14-27. [CrossRef]

91. Lu, G.; Li, C.; Liu, P. UV inactivation of milk-related microorganisms with a novel electrodeless lamp apparatus. Eur. Food. Res. Technol. 2011, 233, 79-87. [CrossRef] 
92. Cameron, M.; McMaster, L.D.; Britz, T.J. Impact of ultrasound on dairy spoilage microbes and milk components. Dairy Sci. Technol. 2009, 89, 83-98. [CrossRef]

93. Välimaa, A.-L.; Tilsala-Timisjärvi, A.; Virtanen, E. Rapid detection and identification methods for Listeria monocytogenes in the food chain-A review. Food Control 2015, 55, 103-114. [CrossRef]

94. Waite-Cusic, J.G.; Diono, B.H.; Yousef, A.E. Screening for Listeria monocytogenes surrogate strains applicable to food processing by ultrahigh pressure and pulsed electric field. J. Food Prot. 2011, 74, 1655-1661. [CrossRef] [PubMed]

95. Bermúdez-Aguirre, D.; Corradini, M.G.; Mawson, R.; Barbosa-Cánovas, G.V. Modeling the inactivation of Listeria innocua in raw whole milk treated under thermo-sonication. Innov. Food Sci. Emerg. Technol. 2009, 10, 172-178. [CrossRef]

96. FDA (Food and Drug Administration). Kinetics of Microbial Inactivation for Alternative food Processing Technologies; FDA Center for Food Safety and Applied Nutrition Report-A Report of the IFT for the FDA of the US Department of Health and Human Services; U.S. Food and Drug Administration: Silver Spring, MD, USA, 2000.

97. Tenenhaus-Aziza, F.; Ellouze, M. Software for predictive microbiology and risk assessment: A description and comparison of tools presented at the ICPMF8 Software Fair. Food Microbiol. 2015, 45, 290-299. [CrossRef] [PubMed]

98. Perez-Rodriguez, F.; Valero, A. Predictive Microbiology in Foods; Springer: New York, NY, USA, 2013; pp. 1-10.

99. Geeraerd, A.H.; Valdramidis, V.P.; Van Impe, J.F. GInaFiT, a freeware tool to assess non-log-linear microbial survivor curves. Int. J. Food Microbiol. 2005, 102, 95-105. [CrossRef] [PubMed]

100. Gérard, A.; El-Hajjaji, S.; Niyonzima, E.; Daube, G.; Sindic, M. Prevalence and survival of Listeria monocytogenes in various types of cheese-A review. Int. J. Dairy Technol. 2018, 71, 825-843. [CrossRef]

101. Cadavez, V.A.P.; Campagnollo, F.B.; Silva, R.A.; Duffner, C.M.; Schaffner, D.W.; Sant'Ana, A.; Gonzales-Barron, U. A comparison of dynamic tertiary and competition models for describing the fate of Listeria monocytogenes in Minas fresh cheese during refrigerated storage. Food Microbiol. 2019, 79, 48-60. [CrossRef] [PubMed]

102. Campagnollo, F.B.; Magalho, L.P.; Kamimura, B.A.; Feliciano, M.D.; Freire, L.; Lopes, L.S.; Alvarenga, V.O.; Cadavez, V.A.P.; Gonzales-Barron, U.; Schaffner, D.W.; et al. Selection of indigenous lactic acid bacteria presenting anti-listerial activity, and their role in reducing the maturation period and assuring the safety of traditional Brazilian cheeses. Food Microbiol. 2018, 73, 2088-2097. [CrossRef] [PubMed]

103. Dogan, C.; Erkmen, O. High pressure inactivation kinetics of Listeria monocytogenes inactivation in broth, milk, and peach and orange juices. J. Food Eng. 2004, 62, 47-52. [CrossRef]

104. Viazis, S.; Farkas, B.E.; Jaykus, L.A. Inactivation of bacterial pathogens in human milk by high-pressure processing. J. Food Prot. 2008, 71, 109-118. [CrossRef]

105. Mussa, D.M.; Ramaswamy, H.S.; Smith, J.P. High pressure (HP) destruction kinetics of Listeria monocytogenes Scott A in raw milk. Food Res. Int. 1998, 31, 343-350. [CrossRef]

106. Xu, H.; Lee, H.-Y.; Ahn, J. High pressure inactivation kinetics of Salmonella enterica and Listeria monocytogenes in milk, orange juice, and tomato juice. Food Sci. Biotechnol. 2009, 18, 861-866.

107. Mishra, N.; Puri, V.M.; Demirci, A. Inactivation and injury of Listeria monocytogenes under combined effect of pressure and temperature in UHT whole milk. J. Food Process. Eng. 2013, 36, 374-384. [CrossRef]

108. Amina, M.; Kodogiannis, V.S.; Petrounias, I.P.; Lygouras, J.N.; Nychas, G.J.E. Identification of the Listeria monocytogenes survival curves in UHT whole milk utilising local linear wavelet neural networks. Expert Syst. Appl. 2012, 39, 1435-1450. [CrossRef]

109. Alpas, H.; Bozoglu, F. The combined effect of high hydrostatic pressure, heat and bacteriocins on inactivation of foodborne pathogens in milk and orange juice. World J. Microbiol. Biotechnol. 2000, 16, 387-392. [CrossRef]

110. Koseki, S.; Mizuno, Y.; Yamamoto, K. Use of mild-heat treatment following high-pressure processing to prevent recovery of pressure-injured Listeria monocytogenes in milk. Food Microbiol. 2008, 25, 288-293. [CrossRef] [PubMed]

111. Reina, L.D.; Jin, Z.T.; Zhang, Q.H.; Yousef, A.E. Inactivation of Listeria monocytogenes in milk by pulsed electric field. J. Food Prot. 1998, 61, 1203-1206. [CrossRef] [PubMed]

112. Zhao, W.; Yang, R.; Shen, X.; Zhang, S.; Chen, X. Lethal and sublethal injury and kinetics of Escherichia coli, Listeria monocytogenes and Staphylococcus aureus in milk by pulsed electric fields. Food Control 2013, 32, 6-12. [CrossRef] 
113. Fleischman, G.J.; Ravishankar, S.; Balasubramaniam, V.M. The inactivation of Listeria monocytogenes by pulsed electric field (PEF) treatment in a static chamber. Food Microbiol. 2004, 21, 91-95. [CrossRef]

114. Gabriel, A.A. Inactivation of Listeria monocytogenes in milk by mmultifrequency power ultrasound. J. Food Process. Preserv. 2015, 39, 846-853. [CrossRef]

115. Gera, N.; Doores, S. Kinetics and mechanism of bacterial inactivation by ultrasound waves and sonoprotective effect of milk components. J. Food Sci. 2011, 76, M111-M119. [CrossRef] [PubMed]

116. Gunter-Ward, D.M.; Patras, A.; Bhullar, M.S.; Kilonzo-Nthenge, A.; Pokharel, B.; Sasges, M. Efficacy of ultraviolet (UV-C) light in reducing foodborne pathogens and model viruses in skim milk. J. Food Process. Preserv. 2018, 42, e13485. [CrossRef]

117. Matak, K.; Churey, J.; Worobo, R.; Sumner, S.; Hovingh, E.; Hackney, C.; Pierson, M. Efficacy of UV light for the reduction of Listeria monocytogenes in goat's milk. J. Food Prot. 2005, 68, 2212-2216. [CrossRef] [PubMed]

118. Gabriel, A.A.; Marquez, G.G.F. Inactivation behaviors of selected bacteria in ultraviolet-C-treated human breast milk. Innov. Food Sci. Emerg. Technol. 2017, 41, 216-223. [CrossRef]

(C) 2019 by the authors. Licensee MDPI, Basel, Switzerland. This article is an open access article distributed under the terms and conditions of the Creative Commons Attribution (CC BY) license (http:/ / creativecommons.org/licenses/by/4.0/). 